\title{
Communicating economic impact assessments: How research results influence decision-maker attitudes toward the local food sector
}

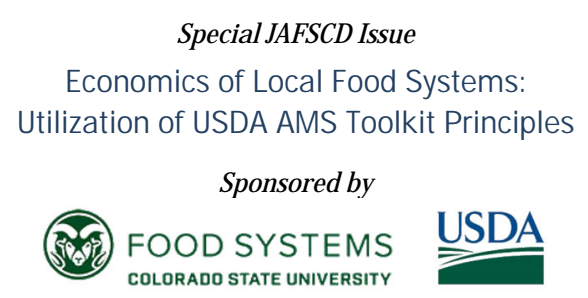

Special JAFSCD Issue

COLORADO STATE UNIVERSITY

\author{
Mallory Lynn Rahe a * \\ Oregon State University \\ Katrina Van D is b \\ Central Oregon Intergovernmental Council \\ Lauren $\mathrm{G}$ win c \\ O regon State University
}

Submitted March 27, 2018 / Revised June 1, July 5, and August 7, 2018 / Accepted August 9, 2018 /

Published online D ecember 20, 2018

Citation: Rahe, M. L., Van D is, K., \& G win, L. (2019). Communicating economic impact assessments: How research results influence decision-maker attitudes toward the local food sector. Journal of A griculture, F ood Systems, and C ommunity D evelopment, 8(Suppl. 3), 95-105. https:// doi.org/ 10.5304/ jafscd.2019.08C.004 p

Copyright ( 2019 by the Authors. Published by the Lyson Center for Civic Agriculture and Food Systems. Open access under CC BY license.

\begin{abstract}
The local food sector continues to evolve as consumer preferences for economic, environmental, and social values create markets for a range of products. Although measuring the economic impact of these complex systems can provide new insights, it

a * C orresponding author: Mallory Lynn Rahe, D epartment of Applied Economics; 240C Ballard Extension Hall, Oregon State University; Corvallis, OR 97331 USA; +1-541-737-1335; mallory.rahe@oregonstate.edu

b Katrina Van Dis, Central O regon Intergovernmental Council; 334 NE Hawthorne Avenue; Bend, OR 97701 USA.

Van Dis is now at High D esert Food and Farm Alliance 4608; 416 NE Greenwood Avenue; Bend, O regon 97701 USA; Katrina@hdffa.org

c Lauren G win, D epartment of Crop Science, O regon State University; 107 Crop Science Bldg.; Corvallis, OR 97331 USA; lauren.gwin@oregonstate.edu
\end{abstract}

remains challenging. This paper provides evidence of the effectiveness of presenting economic impact results to decision-makers as a way to increase public-sector interest in developing a small and growing local food system. Surveys of local leaders and statewide service providers indicate that most local decision-makers who were presented with the economic impact results say they are now more supportive of local food system development, especially in rural areas. In this region, both producing the economic impact study and pursuing a strategy for communicating the results of this study have promoted thinking about the potential of local food production in new ways and have informed conversations with policy-makers.

Funding Disclosure

This study was supported by funding from the Ford Family Foundation in Roseburg, O regon. 


\section{Keywords}

Economic Impact Assessment, Economic Multipliers, Local Food Producers, USD A Local Food Systems Toolkit

\section{Introduction and Literature Review}

The continued growth and long-term viability of local food systems depend on public and private investment of financial, political, and social capital. In pursuit of this investment, food system practitioners increasingly are identifying ways to measure and communicate the multifaceted benefits of local food systems (Brown, Goetz, Ahearn, \& Chyi-lyi, 2013; Lev, Brewer, \& Stephenson, 2003; Sharp, Clark, D avis, Smith, \& McCutcheon, 2011). Economic impact in particular is thought to be a critical and convincing metric. While this is relatively easy to measure compared to other impacts of food systems, there is still tension and confusion about how to measure it accurately. Furthermore, economic impact assessments have little impact themselves if results are not effectively communicated to decision-makers (D ruker, 2015). Little research has focused on the effectiveness of communicating these results to decision-makers.

Economic input-output studies are commonly used to estimate how jobs and sales in one part of the economy are connected to jobs and sales in other parts of the economy. All of this related economic activity can be measured as the "economic impact," which also produces various multipliers that compare activity in one sector to related activity in the rest of the economy. A local food system is a unique economic activity because it is not well measured by existing data sources and has no standard definition. To address these modeling challenges, the Agricultural Marketing Service of the U.S. D epartment of Agriculture (USD A AMS) created an Economic Impact Toolkit (Thilmany McFadden et al., 2016). Conner, Becot, and Imrie (2016) provide an overview of the Toolkit's seven modules. Hughes (2003) explains economic input-output studies, their policy uses, and their limitations to practitioners. A collection of published input-output studies that model the economic impacts of many different aspects of local food systems can be found at the website https:/ / localfoodeconomics.com/.
Even with the Toolkit, estimating the economic impact of the local food sector requires careful consideration of the local economy and the economic activity being modeled (Bauman \& Thilmany McFadden, 2017). These limitations are both encouraging the development of alternative measures and methods for estimating local food system impacts (Miller et al., 2015; Watson, Cooke, Kay, Alward, \& Morales, 2017) and informing the ongoing efforts of the USD A AMS, which released a simplified tool for estimating economic impact, the Local Food Impact Calculator, in January 2018.

In this paper, we first briefly describe the Central O regon region and the economic impact assessment of local food producers completed as a partnership between O regon State University Extension, the Central O regon Intergovernmental Council, and the High Desert Food and Farm Alliance. The primary contribution of our paper is a study of the effectiveness of presenting economic impact results to regional and statewide audiences. The purpose of our presentations was to increase public-sector interest in supporting local food system development. In our methods and results sections, we describe the survey we used to collect audience reactions and changes in attitudes. In our discussion section, we reflect on divergent views among the attitude changes we documented and the study's limitations.

Central 0 regon and the $\mathrm{E}$ conomic Impact

A ssessment in Brief

For the economic impact assessment, we focused on small to midsized local food producers, both crop and livestock, who primarily, but not exclusively, marketed their products within Central 0 regon. In this section we describe the agriculture and local food sector within the Central O regon region, briefly summarize our approach to conducting the economic impact assessment, and describe our primary economic impact results.

A griculture and the L ocal F ood Sector in the Three C ounty Region of $\mathrm{C}$ entral $\mathrm{O}$ regon Central O regon is a region nearly the size of New Hampshire, located on a high desert plateau on the east side of the Cascade Mountain range. This mountain range separates the region from the 
Willamette Valley, which holds the majority of the state's population. Containing Crook, Deschutes, and Jefferson counties, the region has high altitudes, an average rainfall of 11 inches $(28 \mathrm{~cm})$, and a four-season climate with a short outdoor growing season that ranges from 60 to 120 days, depending on elevation (D etweiler, D ouville, Kemp, \& Stephan, 2015). Most farms and ranches in the region, similar to farms statewide, are small in size, have low total sales, and market only a small portion of their products through direct channels.

The 2012 USD A Agricultural Census reported that there were 2,308 farms in the three-county region in 2012; $24 \%$ were $1-9$ acres $(0.4-3.6$ hectare), and an additional $41 \%$ of all farms were 10-49 acres (4.1-19.8 hectare) (USD A National Agricultural Statistics Service, 2014). Eighty-two percent of all farms earned less than US\$25,000 in annual gross sales. The region's most valuable agricultural products, by sales revenue, were cattle and calves, and hay. The region has experienced growth in the number of farms producing vegetables, melons, and potatoes; berries; and fruit and nuts. Sixteen percent of farms in the region engaged in direct marketing compared to $19 \%$ statewide, and per-farm sales of these direct-marketing farms, averaging US\$3,319, was about half the state average.

The Central O regon region has lagged in local food production compared to the Willamette Valley and Southern O regon regions, largely due to the difficult growing conditions. Deschutes County contains the city of Bend, the nation's sixth fastestgrowing metropolitan area, with a population of 94,520 people in 2017. This city anchors the three-county region and has provided an important source of demand in a largely rural area. Each of the two neighboring counties, Crook and Jefferson, has approximately 20,000 residents (see Figure 1).

In this context of growth - both the city's population and the number of potential local food producers - two organizations, the Central Oregon Intergovernmental Council (COIC), a council of governments for the region, and the High D esert Food and Farm Alliance (HDFFA), a nonprofit, work with a network of farmers and ranchers to develop the local food sector's capacity. Through these efforts, COIC and HDFFA identified the need to document the sector's economic impact and partnered with the Oregon State University (OSU) Extension Service to conduct the economic impact analysis.

E conomic Impact A ssessment

Working together, staff from the three organizations used the USD A Toolkit to design an economic impact study with the following parameters:

- Assess the impact of local food system producers using primary survey data;

- Analyze the impact of two types of local
Figure 1. Central Oregon Counties and the City of Bend Shown within the State of Oregon

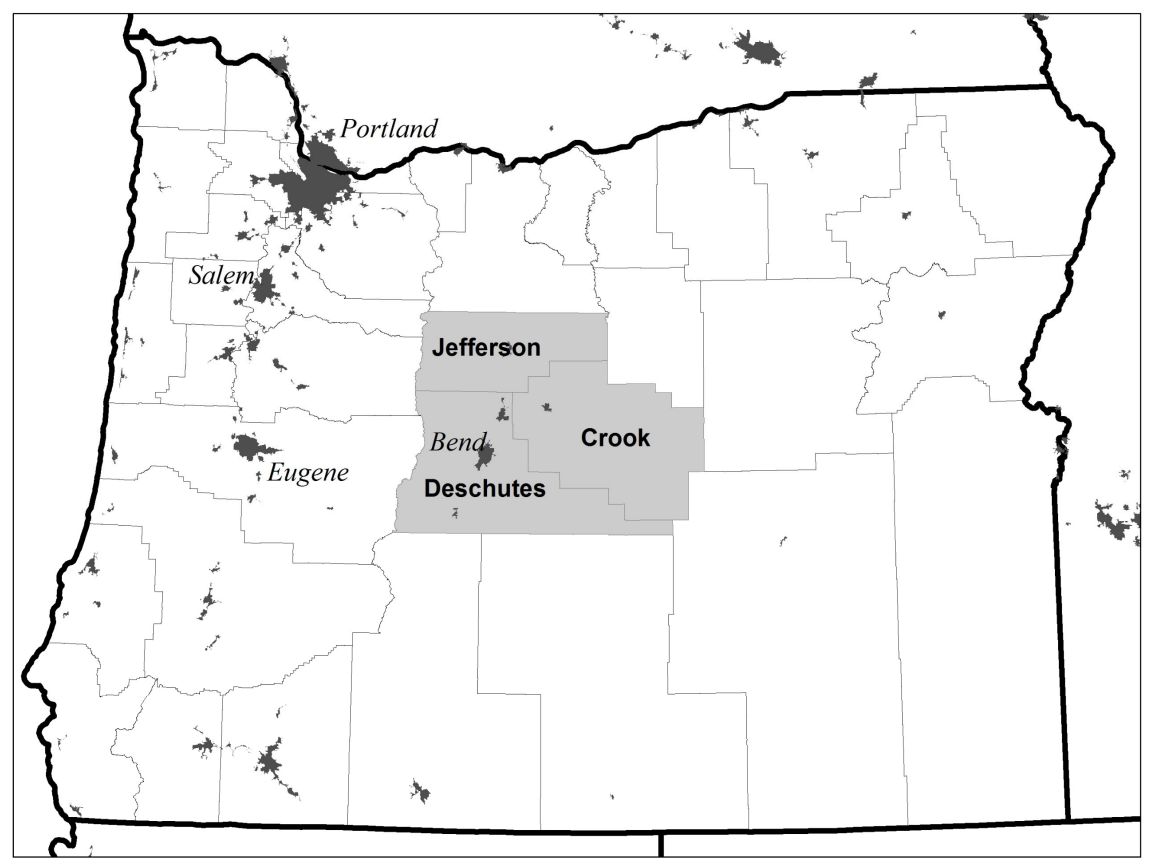


food farms: crop-focused and livestockfocused;

- Measure current direct impact (using 2014 Schedule F tax form data);

- Create two scenarios of potential future impact that considered resource constraints and opportunity costs; and

- Use this study to pilot the use of the Toolkit in O regon and evaluate the value of these studies for other regions of the state.

This study is similar to and was modeled after two other recent analyses that focused on estimating the economic impact of local food producers and used surveys to collect expenditure data from producers. Unlike this study, both of the previous efforts focused on mature local food systems: one in a three-county region of California (Hardesty et al., 2016) and one in a multicounty study in the state of New York (Jablonski, Schmit, \& Kay, 2016). This study of Central O regon also analyzed expanding the local food system by adding a food hub following the methodology in Jablonski et al. (2016) using the expenditures of an average U.S. food hub (Hardy et al., 2016). The methods, processes, and results of the Central O regon economic impact assessment are described in detail in the final report (Rahe, Van D is, Weiland, \& $\mathrm{G}$ win, 2017).

Using 2015 data, the Central O regon analysis found that local food producers have a direct impact of supporting 28 full- and part-time jobs, and generating US\$1.5 million in sales and US $\$ 248,000$ in wages and salaries from their farm operations. The purchases made by local food producers supported an additional 7 jobs, US\$173,500 in labor income, and US\$679,000 in sales across the broader economy (indirect effects). A final level of economic activity associated with local food producers can be calculated from the household spending of earnings and profit from farmers, farmworkers, and the owners and workers in businesses that supply farmers (induced effects). A portion of these activities generate additional economic impact when households buy goods and services within the region. An additional 4 jobs, US $\$ 148,000$ in labor income, and US\$444,000 of sales are supported by the household spending of wages and profits from local food producers and their input suppliers. This estimate is likely conservative for three reasons: we were unable to survey all producers, more than one-third of all producers were planning to expand their operations, and we removed all capital expenditures from the model. It is important to note, however, that local foods are a small part of this region's economy. In total, the input-output modeling software IMPLAN estimates that the three-county region generates US $\$ 8.2$ billion in gross regional product and 114,060 full- and part-time jobs.

\section{Methods}

Once the economic impact estimates were complete, COIC and HDFFA worked with Rural D evelopment Initiatives, a statewide nonprofit, to develop a communication strategy that integrated the economic impact results with prior research on a regional food hub. This communication strategy included a factsheet highlighting the study's results, a presentation, and a press release that resulted in the publication of an article in the region's main newspaper (D itzler, 2017). Additionally, CO IC organized a series of meetings with the region's most influential local leaders and a group of statewide service providers to present the study's findings.

We explored our central research question, "How does the presentation of a local food system's economic impact results change the attitudes of elected officials and statewide service providers?" by collecting surveys at the end of each presentation for a qualitative study. OSU Extension faculty designed a survey containing both fivepoint ordinal Likert-scale questions and openended questions to produce a descriptive analysis. We deliberately kept our survey short to encourage completion rates, although this limited the depth of information collected. Because of our purposive survey sample design, the selection of our small target audience was intentional. This audience consisted of rural and urban elected officials within the region as well as statewide service providers. These methods allowed us to explore how economic impact assessment results could influence attitudes toward Central O regon's local food system and provide some insight into the 
value and effectiveness of replicating this study in other regions of O regon. Next, we describe our audiences, survey instruments, and response rates.

COIC staff presented the economic impact study to five different audiences, totaling 34 people. The selection of these audiences was a purposive sampling strategy, which sought to reach people COIC thought could take action most directly after hearing the results. Twenty-three people, or $68 \%$ of all audience members, returned surveys after presentations (see Table 1). The communication strategy targeted public decisionmakers within the region, including the three elected county commissioners and some staff of each county, and the City of Bend Economic D evelopment Advisory Board, which includes the business owners of major industries and economic developers for the region's largest urban area. For this strategy, we also convened a meeting with Regional Solutions, a state government agency with offices across the state that connect local projects to state resources. This meeting included local staff of the agency as well as the staff of invited state agencies, including both the 0 regon D epartment of Agriculture and Business O regon, the state's economic development agency. In our results, we separate these audiences into staff of state agencies, decision-makers for primarily rural areas (Crook and Jefferson counties), and decision-makers for primarily urban areas (D eschutes County and the city of Bend).

COIC and HDFFA first concentrated on scheduling meetings with the regions' most influential, elected leaders with resources to invest in publicly supported economic development. This

Table 1. Survey Audiences and Response Rates

\begin{tabular}{llcccc}
\hline $\begin{array}{l}\text { Date of } \\
\text { Presentation }\end{array}$ & Description & $\begin{array}{c}\text { Rural, Urban, or } \\
\text { State Agency }\end{array}$ & Total N & $\begin{array}{c}\text { Returned } \\
\text { Surveys }\end{array}$ & $\begin{array}{c}\text { Response } \\
\text { Rate }\end{array}$ \\
\hline $2 / 28 / 2018$ & Deschutes County & Urban & 10 & 4 & $40 \%$ \\
$2 / 5 / 2018$ & City of Bend & Urban & 8 & 3 & $38 \%$ \\
$2 / 1 / 2018$ & Regional Solutions & State Agency & 5 & 5 & $100 \%$ \\
$1 / 24 / 2018$ & Jefferson County & Rural & 7 & 7 & $100 \%$ \\
$1 / 17 / 2018$ & Crook County & Rural & 4 & 4 & $100 \%$ \\
\hline Total & & & 34 & 23 & $68 \%$ \\
\hline
\end{tabular}

$1 \underline{\mathrm{https}: / / \text { centerforsmallfarms.oregonstate.edu/ communityfoodsystems }}$ three-county region also includes seven other incorporated cities, six of which have populations of fewer than 10,000 people. By not focusing on these smaller cities, our results best describe the perceptions of individuals whose jobs require them to think about economic development for the state, for both rural and urban counties, and a major urban area in the region.

All audiences received a one-hour, in-person presentation from COIC staff. Paper surveys were distributed at the end of the meeting as the COIC staff members left, allowing audience members to complete the survey in the room or later. These surveys were anonymous and collected limited personally identifiable information in an effort to encourage response. They were then collected by the staff of the respective organizations, scanned, and returned to COIC within one to two days after each presentation.

The presentations to each audience focused on the results of the study, with an emphasis on how these results fit with prior studies in order to prompt discussion about the potential of creating a regional food hub. The survey included seven questions to address the following three topics:

1. How did the study's findings change your support for local food systems?

2. What was the most important information you took from the presentation?

3. What next steps should occur now that the study is finished?

The survey and other information about the study can be accessed online. ${ }^{1}$

We asked additional questions to control for beginning levels of support and knowledge of local food systems and economic impact analysis. These questions also allowed us to understand how predisposed participants were to positively receiving these results. COIC was designated as a 
Central 0 regon after hearing the study results (see Figure 3). This effect of the presentation was most likely among respondents in rural Crook and Jefferson counties. The study's results did not change the attitudes of four participants, and decreased one participant's interest in supporting the expansion of the local food system. Representatives of three state agencies had a mostly positive reaction to hearing the study's results, as four out of five indicated the results increased their interest in supporting the expansion of the local food system in the region.

(2) W hat was the most important information participants took from the presentation?

Along with gauging the participants' overall perceptions of the value of the study, we asked all respondents to report the most important thing they heard during the presentation and subsequent discussion through an open-ended question (see Table 2). Participants primarily mentioned the importance of hearing about potential job and economic growth, followed by the importance of gaining new information about the Central O regon

Figure 3. Responses to Survey Question Regarding the Presentation's Effect on Interest in Supporting the Local Food System

Most respondents reported hearing the economic impact findings increased their interest in supporting local food systems.

How did this presentation affect your interest in supporting the expansion of the local food system?

Strongly increased -

Increased -0000000000000

No effect $-\infty, 00$

Decreased

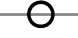

Strongly decreased

O Rural - State Agency OUrban local food system. These comments reflect the focus of the presentations and the fact that the participants were selected because they are positioned to intervene and support, or block support of, public investment in this sector.

(3) W hat next steps should ocaur now that the study is finished?

Across our sample, there was not a strong consensus on what should happen next as local respondents envisioned a range of potential next steps for the region. Fourteen of the 23 people who filled out our survey chose to answer this open-ended question. Four felt that CO IC and HDFFA should explore new partnerships in their efforts for expansion. Two said the region should focus on expanding access to local food by making it more widely available. O ne person made a similar comment about expanding access, but stressed that there should also be focus on equitable access to local foods. Two recommended pursuing value-added options, including building the food hub and investing in local processing capacity. O ne respondent advocated for additional consumer education of the benefits of buying local food and another respondent suggested pursuing more analysis before making investments in a food hub.

Although most comments were positive, two respondents from urban areas elaborated on their negative views. O ne respondent reported that the low wages reported in the study confirmed their opinion that commodity agriculture was superior, writing, "I think small farms in Central O regon are inefficient. Also what about the seed farm in Madras that supplies close to $50 \%$ of global carrot seeds? What about hemp? Farmers/ ranchers don't only grow things we eat. Sheep farm in Madras provided wool to Olympics." Another respondent said the marketperhaps via a cooperative- should address the gaps in the food system, not the government.

The economic impact assessment for Central O regon was published in 
Table 2. Responses to the Open-ended Survey Question, "What was the most important thing you heard today?"

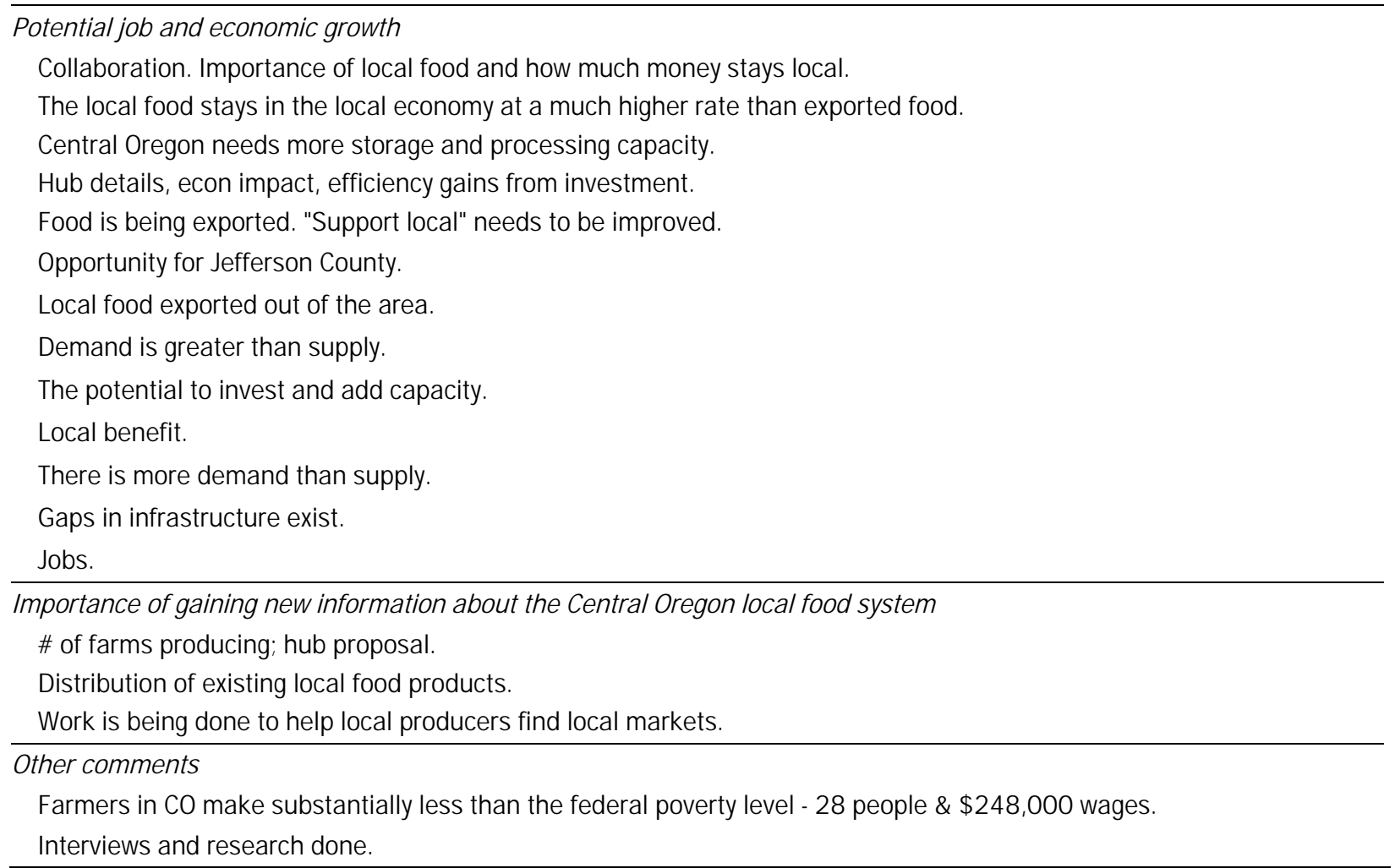

late 2017, and outreach using the study's results had been underway for six months as of this writing. It will be important to continue tracking the effectiveness of this outreach and what kind of changes, if any, are made by public and private actors. However, our findings suggest that even this initial communication has had a generally positive effect: most local decision-makers indicated on the surveys that they are now more inclined to support local food system development, especially in more rural areas. Central Oregon local food system advocates, led by COIC and HDFFA, are now refining a business plan for a food hub and supporting additional farmer education as they continue to invest in expanding the capacity of the local food system.

State agencies have also responded positively. As a result of hearing about the economic impacts, Business O regon, the state's economic development department, has committed to working with COIC by joining a steering committee and by helping to identify funding and additional technical expertise for further research on food hubs. The O regon D epartment of Agriculture is interested in becoming more connected to local food producers in the region, beginning with providing on-farm food safety workshops in Central Oregon. The Regional Solutions staff in Central O regon has actively connected COIC to new agencies and grants since the presentation.

We also presented these economic impact results to a network of local food system practitioners and advocates in O regon. Consequently, two other regions with active local food sectors have expressed interest in pursuing similar studies and are looking for resources to fund the producer interviews and analytical components of the work. In the meantime, practitioners report using the Central O regon study's results in their own conversations about local food system development as an example of a system "close to home." 


\section{Discussion}

We found the presentation of the results had a stronger and more positive impact among decisionmakers in rural counties and the state service providers who work with Regional Solutions. The two urban audiences, D eschutes County and the city of Bend, had lower response rates and responded less positively to the study. Two survey respondents were openly critical of the idea of using public investments to support industry expansion. With just two audiences, our sample of urban decision-makers is small, and while we do not want to overgeneralize from these two responses, it is worthwhile to discuss this opposing viewpoint. This view may be partially explained by differences between the scale of the local food industry and those respondents' prior experiences in economic development. However, the responses of urban audiences also illustrate the ongoing challenges in both collecting accurate data from this industry and exclusively relying on economic impact analysis to justify public investment in the local food sector.

Local foods are not an economic driver of the urbanizing Central Oregon economy and, as a sector, are economically dwarfed by the region's rapidly expanding tourism and construction sectors. Still, where some respondents see only the inefficiencies of local food, others see a small but growing industry that is producing more economic activity than expected.

Furthermore, depending on how the conversation is framed, communicating the results of an economic impact assessment of just one segment of the local food system can be problematic. The total number of jobs, wages, and sales associated with Central O regon producers were small. COIC and HDFFA built a communication strategy that emphasized the economic impact results from the growth scenarios. Framing the conversation in this way was meant to demonstrate the potential of the industry if additional value chain businesses were in place to support the expansion of small-scale, local production. The presentation included a goal to build a food hub, but did not formally ask for resources. COIC and HDFFA have been analyzing different aspects of the local food system for nearly 10 years and felt that knowing the current and potential economic impacts was necessary to fill a gap in information. In an effort to keep the sessions short and understandable, the presentations largely focused on sharing the economic impacts as well as on providing a thorough definition of a local food system. Based on our initial findings, we suggest that it may be more effective - although more resource-intensive- to garner public investments by presenting a more comprehensive set of impacts for small and growing local food systems. This could entail combining an assessment of economic impacts with evidence of small business development and of health impacts, as well as staying aware of ongoing research into the environmental (Lee, Miller, \& Loveridge, 2017) and social benefits of local food systems.

Study L imitations and A reas of Future Research Both our IMPLAN model and our audience surveys rely on information from a small number of intentionally chosen individuals. Both efforts establish a baseline understanding of the local food system and sentiments about supporting that system. This baseline will be updated with future assessments. The IMPLAN model reflects the business operations of networked and engaged local food producers. These producers are partand full-time farmers and ranchers who operate businesses with a range of sales in both direct and wholesale markets. It is impossible to know how much of the total local food activity we captured in our data. Furthermore, the audience members for our presentations were not random but were purposefully chosen because of their positions as elected leaders, economic development decisionmakers, or resources. We thus chose to present this information to people who would be most likely to take action after learning about this study and its results. O ur findings do not indicate how this work would be perceived by other groups and individuals.

\section{Conclusion}

After 10 years of efforts to promote and expand the local food system in Central O regon, COIC and HDFFA decided to partner with OSU Extension to pursue an economic impact assessment. The purpose of this assessment was to broaden the 
conversation about the local food sector to traditional economic developers and decision-makers in the region. Following a specific communications strategy, we presented the assessment and its findings to 34 decision-makers within the three-county region. In this paper, we reported a descriptive summary of communicating the results of this local food economic impact assessment to decisionmakers. This study provided a first look at the value of the assessment to the practitioners and region that requested it.

The estimate of economic impact provided by our study did fill a recognized need for local food stakeholders within the region. The results have value, especially when paired with existing studies, and also speak directly to local decision-makers' concerns and values, such as jobs, wages, and economic growth. The results of a small and developing system, however, have less influence with urban leaders who are more familiar working with major industries.
It is too early to tell whether these results have provided enough additional information to encourage the local investment needed to expand the Central O regon food system. However, the communication of this assessment has broadened the conversation about local food systems within the region and the state in important ways. COIC and HD FFA have been able to gain the attention of people in key leadership positions and initiate new conversations about the local food system and its potential place in the region's evolving economy.

\section{Acknowledgments}

We thank Jess Weiland at the High D esert Food and Farm Alliance for conducting producer interviews for the economic impact analysis, and all of the Central 0 regon farmers and ranchers who shared or considered sharing detailed financial information about their farm operations for the IMPLAN model.

\section{References}

Bauman, A., \& Thilmany McFadden, D . (2017). Exploring localized economic dynamics: Methods-driven case studies of transformation and growth in agricultural and food markets. E conomic D evelopment Q uarterly, 31(3), 244-254. https:// doi.org/ 10.1177/ 0891242417709530

Brown, J. P., G oetz, S. J., Ahearn, M. C., \& Liang, C.-I. (2013). Linkages between community-focused agriculture, farm sales, and regional growth. E conomic D evelopment Q uarterly, 28(1), 5-16. https:/ / doi.org/ 10.1177/ 0891242413506610

Conner, D ., Becot, F., \& Imrie, D . (2017). Critical reflections on the USD A local food economics toolkit. Journal of A griculture, F ood Systems, and C ommunity D evelopment, 7(2), 117-125. https:/ / doi.org/ 10.5304/ jafscd.2017.072.001

Detweiler, A. J., D ouville, L., Kemp, V., \& Stephan, T. (2015). G rowing vegetables in C entral 0 regon: C rook, D eschutes, and Jefferson C ounties (Report No. EM 9128). O regon State University Extension Service. Retrieved from https:// catalog.extension.oregonstate.edu/ em9128

Ditzler, J. (2017, November 22). A portrait of Central O regon small farms and ranches. Bend Bulletin. Retrieved from http:/ / www.bendbulletin.com/ newsroomstafflist/ 5758099-151/ a-portrait-of-central-oregon-small-farms-and

D rucker, J. (2015). Economic impact analysis among rapid change: Challenges, strategies, and examples from defense communities. Journal of Planning E ducation and Research, 35(4), 401-418. https:/ / doi.org/ 10.1177/ 0739456X 15586626

Hardesty, S., Christensen, L. O., McGuire, E., Feenstra, G., Ingels, C., Muck, J., ... O neto, S. (2016). Economic impact of local food producers in the Sacramento region. D avis: University of California, D avis, Agriculture and Natural Resources. Retrieved from http:// sfp.ucdavis.edu/pubs/Economic Impact_Reports/

Hardy, J., Hamm, M., Pirog, R., Fisk, J., Farbman, J., \& Fischer, M. (2016). Findings of the $2015 \mathrm{~N}$ ational F ood H ub Survey. East Lansing: Michigan State University Center for Regional Food Systems \& The Wallace Center at Winrock International. Retrieved from http:/ / foodsystems.msu.edu/ resources/2015-food-hub-survey

Hughes, D.W. (2003). Policy uses of economic multiplier and impact analysis. C hoiees (Q uarter 2), 25-29. Retrieved from http:/ / www.choicesmagazine.org/ 2003-2/ 2003-2-06.htm

Jablonski, B. B. R., Schmit, T. M., Kay, D . (2016). Assessing the economic impacts of food hubs on regional economies: A framework that includes opportunity cost. A gricultural and Resource E conomics Review, 45(1), 143-172. https:// doi.org/ 10.1017/ age.2016.9 
Lee, G. E., Miller, S. R., \& Loveridge, S. (2017). Modelling local food policy and greenhouse gas emission due to transportation. Journal of Regional A nalysis and Policy, 47(1), 75-87. Retrieved from http:// www.jrap-journal.org/ pastvolumes/2010/ v47/ index471.html

Lev, L., Brewer, L., \& Stephenson, G . (2003). Research brief: H ow do farmers' mark ets affect neighboring businesses? (O regon Small Farms Technical Report No. 16). Corvallis: O regon State University Extension. Retrieved from http:/ / smallfarms.oregonstate.edu/ sites/ default/ files/ publications/ techreports/ TechReport16.pdf

Miller, S. R., Mann, J., Barry, J., Kalchik, T., Pirog, R., \& Hamm, M. W. (2015). A replicable model for valuing local food systems. Journal of A gricultural and A pplied E conomics, 47(4), 441-461. https:/ / doi.org/ 10.1017/ aae.2015.19

Rahe, M. L., Van D is, K., Weiland, J., \& G win, L. (2017). E conomic impad of local food producers in C entral 0 regon. Corvallis: O regon State University. Retrieved from https:/ / appliedecon.oregonstate.edu/ biblio/ economic-impact-local-food-producers-central-oregon

Sharp, J. S., Clark, J. K., D avis, G. A., Smith, M. B., \& McCutcheon, J. S. (2011). Adapting community and economic development tools to the study of local foods: The case of Knox County, O hio. Journal of $\mathrm{E} x$ tension, 49(2). Retrieved from https:// www.joe.org/ joe/ 2011april/ pdf/JOE_v49_2a4.pdf

Thilmany McFadden, D ., Conner, D., D eller, S., Hughes, D ., Meter, K., Morales, A., ... Tropp, D . (2016). The economics of local food systems: A toolkit to guide community discussions, assessments, and choios. U.S. D epartment of Agriculture, Agricultural Marketing Service. Retrieved from www.ams.usda.gov/ sites/default/ files/media/ EconomicsofLocalFoodSystemsToolkit.pdf

U.S. D epartment of Agriculture, National Agricultural Statistics Service. (2014). 2012 C ensus of A griallure County E stimates for 0 regon [D ata file]. Retrieved from https:/ / quickstats.nass.usda.gov/

Watson, P., Cooke, S., Kay, D ., Alward, G., \& Morales, A. (2017). A method for evaluating the economic contribution of a local food system. Journal of A gricultural and Resouro E conomics, 42(2), 180-194. Retrieved from http:/ / www.waeaonline.org/ UserFiles/ file/ JARE42.2May20174Watson180-194.pdf 